\title{
Удосконалення технології організації групових поїздів оперативного призначення на основі синхронізації графіку руху на станціях обміну груп вагонів
}

Робота присвячена питанню автоматизації розробки спеціалізованого розкладу просування ланцюгів групових поїзів з послідовною заміною груп вагонів одразу на декількох технічних станціях за напрямками слідування вагонопотоків. Розроблено математичну модель для синхронізації графіку руху групових поїздів на станціях обміну груп вагонів на основі визначеного рачіонального варіанту об'єднання струменів вагонопотоків згідно до плану формування поӥздів (ПФП).

Ключові слова: графік руху поӥздів, групові поӥзди, синхронізачія розкладу, автоматизачія.

\begin{abstract}
Вступ
Одним із напрямків розвитку залізничної транспортної системи України $є$ оптимізація плану формування поїздів 3 урахуванням взаємодії 3 графіком руху поїздів за принципом підвищення швидкості та точності доставки вантажів. Однією із найбільш конкурентоспроможних технологій щодо оперативного прискорення просування вагонопотоків малопотужних дальніх струменів $\epsilon$ технологія погодженої організації обігу групових поїздів 3 обміном груп вагонів на технічних станціях полігону мережі.
\end{abstract}

\section{Постановка задачі \\ Введення обігу групових поїздів дозволяє скоротити простій вагонів під накопиченням, вивільнити за маршрутом прямування технічні станції 3 недостатньо розвинутими сортувальними пристроями для переробки дільничних вагонопотоків, і прискорити рух вагонів до станцій призначень [1]. Як показує практика незважаючи на переваги, така технологія має деякі недоліки, головним 3 яких $€$ складність синхронізації по прибуттю на станціях обміну груп вже спланованих варіантів обігу групових поїздів в умовах відсутності жорсткого графіку руху. На даний час задача розробки розкладів руху групових поїздів вирішується за допомогою експертних методів в ручному режимі [2]. Головним недоліком такого підходу $\epsilon$ неможливість ув'язки графіку руху для великої кількості групових поїздів на полігоні мережі значної розмірності. За таких умов особливої актуальності набуває вирішення задачі на основі автоматизації розробки спеціалізованого розкладу просування ланцюгів групових поїздів з послідовною заміною груп вагонів одразу на декількох технічних станціях за напрямками слідування вагонопотоків.}

(C) А.М. Киман, 2015

\section{Вирішення задачі}

Приймаючи до уваги складність рішення поставленої задачі в роботі запропоновано розробити математичну модель для розрахунку розкладу руху групових поїздів на сітьовому рівні. Головною особливістю графіку руху групових поїздів $\epsilon$ важливість встановлення часу відправлення 3 початкової станції та відповідно часу прибуття на станцію обміну груп вагонів, де розклад повинен враховувати час проведення маневрів на станції по обміну груп вагонів, закінчення формування групового поїзду та відправлення даного составу на наступну станцію обміну груп вагонів 3 можливістю ув'язки прибуття даного составу з прибуттям групового поїзда 3 іншого напрямку. За таких умов в роботі мережу напрямків руху групових поїздів можна представити у вигляді орієнтованого графу $\mathrm{G}(A, \bar{N})$, де $A$ - множина вершин, що представляють станції обміну груп вагонів, $1 \leq s \leq S$, тоді як $\bar{N}-$ множина дуг, що відповідають маршрутам слідування групових поїздів та представляють струмені поїздопотоків, $i \neq j$, $i=\overline{1, N}, j=\overline{1, N}$, рис. 1. Рух поїздів по дугам графу здійснюється тільки в одному напрямку. Позначимо через $S_{j}-$ множину всіх станцій для обміну груп вагонів на $j$-му маршруті руху групового поїзда.

Враховуючи, що відповідно до технології організації групового поїзду на кожній станції $\boldsymbol{S}$ здійснюється операція по обміну груп вагонів тривалість якої обмежена мінімальним нормативним часом, до моделі запропоновано ввести параметр $H \min _{i j}^{S}-$ мінімальний інтервал між прибуттям та відправленням двох поїздів на станції обміну груп вагонів, що необхідний для проведення операцій 3 обміну груп вагонів. Слід зазначити, що у випадку занадто довгого часу очікування поїзда на станції 
обміну груп, дана технологія може стати економічно недоцільною 3 причини збільшення часу простою вагонів. Отже, необхідним $\epsilon$ визначити параметр $H \max _{i j}^{s}$ - максимальний інтервал між прибуттям та відправленням групового поїзда на станції обміну груп вагонів, $H \max _{i j}^{s} \geq H \min _{i j}^{s}$ [3]. Для моделювання фактичного часу знаходження групового поїзда на станції обміну груп вагонів слід ввести змінну $H_{i}^{s}$. Даний підхід щодо встановлення допустимих термінів очікування поїздів у вузлах $H \min _{i j}^{s} \leq H_{i}^{S} \leq H \max _{i j}^{S}$ забезпечить надійність технології організації групових поїздів на мережі та обмежить область пошуку оптимальних рішень.

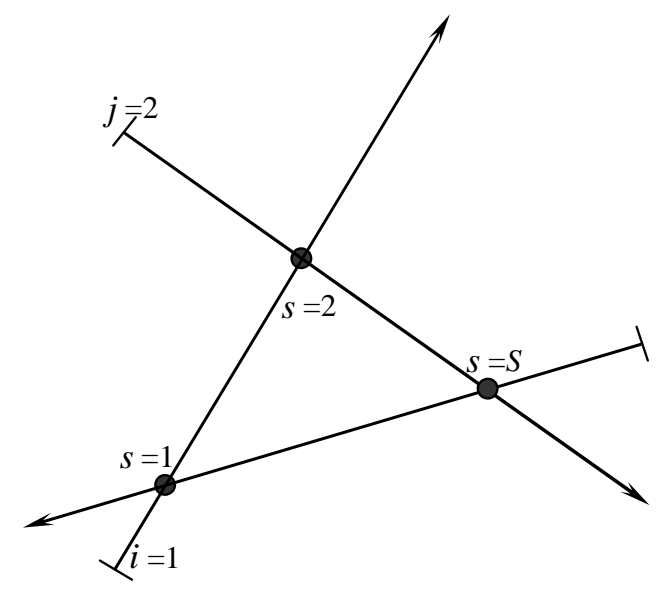

Рис. 1. Мережа напрямків руху групових поїздів та станцій обміну у вигляді орієнтованого графу $\mathrm{G}(A, \bar{N})$

Позначимо через $T$ - період планування, який відповідно до постановки задачі слід прийняти рівним добі, $T=1440 x в$. За таких умов горизонт планування визначається в межах $[0, T]$. На кожному маршруті слідування групового поїзда може бути декілька составів, тому необхідним $є$ позначити через $\mathrm{f}_{i}$ - кількість відправлень (частота) групових поїздів або кількість поїздів, що заплановані на маршруті $i$ в інтервалі $[0, T], k=\overline{1, \mathrm{f}}$. Для рішення задачі розробки розкладу групових поїздів в межах постановки математичної моделі необхідним $є$ визначення часу відправлення кожного поїзда $k$ на маршруті слідування $i$, тобто змінної $X_{k i}$. На інтервал між поїздами на одному маршруті необхідно встановити обмеження, при якому різниця між часом послідовного відправлення двох поїздів $X_{k i}$ та $X_{(k+1) i}$ не повинна бути менша ніж мінімальний інтервал між поїздами
$I \min _{i}$ або більше встановленого заздалегідь максимального значення міжпоїздного інтервалу $I \max _{i}$ [4, 5]. Час відправлення першого групового поїзда $k=1$ на кожному маршруті $i$ повинен відбуватися в межах інтервалу $\left[0, I \max _{i}\right]$. Для моделювання різних варіантів інтервалів відправлення на маршруті групових поїздів необхідно ввести до моделі змінну $I_{(k, k+1) i}$, яка повинна приймати значення в межах інтервалу [I $\left.\min _{i}, I \max _{i}\right]$.

Час руху групового поїзда від початкової станції відправлення маршруту $i$ до станції обміну груп вагонів $S$ та час руху між станціями обміну груп вагонів заздалегідь відомі параметри відповідно $t_{k i}^{s}$ та $t_{k i}^{s, s+1}$. Час прибуття поїздів на станцію обміну груп обчислюється шляхом додавання часу відправлення поїзда до часу, що необхідний для слідування поїзда до станції $s$, тобто $d t_{k i}^{s}=X_{k i}^{s}+t_{k i}^{s}$. Час відправлення поїздів із станції обміну груп $a t_{k i}^{s}=X_{k i}^{s}+t_{k i}^{s}+H_{i}^{s}$. За аналогічним підходом можна визначити час прибуття та відправлення поїзда для наступної станції обміну груп вагонів $s+1$ на маршруті $i$. Тривалість операції по обміну груп вагонів на станції $S$ між груповими поїздами можна визначити за виразом $W t_{k, i j}^{s}=a t_{k, j}^{s}-d t_{k, i}^{s}$, рис. 2 .

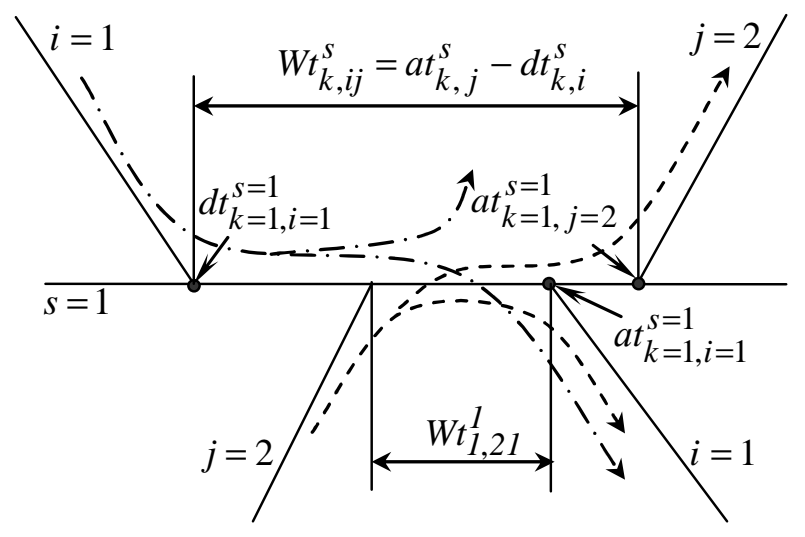

Рис. 2. Схема допустимого варіанту проходження групових поїздів на станції обміну груп вагонів

Згідно вище наведеного математичну модель для синхронізації графіку руху групових поїздів на станціях обміну груп вагонів можна представити у вигляді цільової функції, яка мінімізує загальний час 
простою груп вагонів на станціях обміну та обмежень виду

$$
\begin{aligned}
& F\left(X_{k i}, H_{i}^{s}, I_{(k, k+1) i}\right)=\sum_{s} \sum_{i} \sum_{j} \sum_{k} W t_{k i j}^{s} \rightarrow \min \\
& \text { де } X_{k, i} \geq 0, X_{1, i} \leq \operatorname{Imax}_{i} ; 1 \leq k \leq \mathrm{f}_{i}, \\
& X_{\mathrm{f}, i} \leq T, 1 \leq i, j \leq N \\
& \operatorname{Imin}_{i}^{s} \leq X_{(k+1) i}-X_{k i} \leq \operatorname{Imax}_{i}^{s}, \quad 1 \leq s \leq S \\
& H \min _{i}^{s} \leq H_{i}^{s} \leq H \max _{i}^{s}, \\
& a t_{k, j}^{s}>d t_{k, i}^{s}, 1 \leq i, j \leq N
\end{aligned}
$$

Обмеження (2) визначає необхідність відправлення першого групового поїзда на кожному маршруті $i$ в межах інтервалу $\left[0, I \max _{i}\right]$. Обмеження встановлює умову при якій відправлення останнього групового поїзда повинен бути в межах планового періоду $T$. Обмеження (4 - 5) визначають необхідність дотримання меж міжпоїздного інтервалу та часу стоянки групового поїзда на станції обміну груп. Обмеження (6) виключає недопустимі варіанти схем проходження групових поїздів на станції обміну груп вагонів, тобто виключається раннє приймання та відправлення групових поїздів на станціях обміну груп вагонів. Слід зазначити рішення запропонованої математичної моделі можливе лише за умови допустимості задачі, тобто при існуванні пропускної спроможності на залізничних дільницях в умовах існування пасажирського руху.

Рішення поставленої задачі оптимізації не представляється складним i можливо здійснити за допомогою методу оптимізації на основі використанням генетичного алгоритму [6].

\footnotetext{
Висновки

Запропонована математична модель дозволить ув'язувати спеціалізовані нитки графіку руху по станціям обміну груп вагонів та встановити постійний розклад обігу групових поїздів згідно до визначеного варіанту об'єднання малопотужних дальніх струменів вагонопотоків. У перспективі на підставі отриманої математичної моделі можна створити автоматизовану систему ув'язки графіку руху для великої кількості групових поїздів на полігоні мережі значної розмірності. Такий підхід дозволить підвищити рівень організації перевезень, прискорити строки доставки вантажу та підвищити конкурентоспроможність залізниць на ринку транспортних послуг.
}

Література

1. Бутько, Т.В. Формування логістичної технології просування вантажопотоків за жорсткими нитками графіку руху поїздів [Текст] / Т.В. Бутько, Д.В. Ломотько, А.В. Прохорченко, К.О. Олійник // Збірник наукових праць. - Харків, УкрДАЗТ, 2009. - №78. - С. 71-75.

2. Грунтов П.С. и др. Управление эксплуатационной работой и качеством перевозок на железнодорожном транспорте [Текст]: Учебник для вузов/ П.С. Грунтов, Ю.В. Дьяков, А.М. Макарочкин и др.; Под ред. П.С. Грунтова. М.: Транспорт, 1994 г. - 543 с.

3. Ceder, A. Creating bus timetables with maximal synchronization [Text]/ A. Ceder, B. Golany, O. Tal // Transportation Research. -2000. - Part A 35. P. 913 -928.

4. Daduna, J. Practical Experiences in Schedule Synchronization [Text]/ J. Daduna, S. Voß, J. Branco, J.P. Paixão // Computer-Aided Transit Scheduling. Springer Berlin Heidelberg. - 1995. - Vol. 430. P. 39-55.

5. Castelli, L Scheduling multimodal transportation systems [Text]/ L. Castelli, R. Pesenti, W. Ukovich // European Journal of Operational Research. - 2004. Vol. 155(3). - Р. 603-615.

6. Рутковская Д., Пилинский М., Рутковский Л. "Нейронные сети, генетические алгоритмы и нечеткие системы [Текст]: Пер. с польск. И.Д.Рудинского. - М.:Горячая линия - Телеком, 2004. -452 c.

Киман А.Н. Совершенствование технологии организации групповых поездов оперативного назначения на основе синхронизации графика движения на станциях обмена групп вагонов. Работа посвящена вопросу автоматизации разработки специализированного расписания продвижения цепей групповых поездов с последовательной заменой групп вагонов сразу на нескольких технических станциях по направлениям следования вагонопотоков. Разработана математическая модель для синхронизации графика движения групповых поездов на станциях обмена групп вагонов на основе заранее определенного рационального варианта объединения струй вагонопотоков согласно плана формирования поездов (ПФП).

Ключевые слова: график движения поездов, групповые поезда, синхронизация расписания, автоматизация. 
Kyman A. The improvement of the technology of group trains of operational designation organization on the basis of traffic schedules synchronization at car groups exchange stations. The work is dedicated to the problem of automation of specialized schedule of group train chains traffic with successive replacement of car groups at several technical stations simultaneously according to the direction of car flow movement.

A mathematical model for group trains traffic schedules synchronization at car groups exchange stations on the basis of the determined reasonable variant of integration of car flows according to the plan of making-up of trains has been developed. The given mathematical model is presented in the form of an objective function which minimizes overall time of car group detention at the exchange stations and restrictions which take into account the observance of the technology of group train handling at group exchange stations, inter-train intervals and the duration of train movement on network divisions. The solution of a mathematical optimization model was proposed to be done on the basis of genetic algorithm application. In the perspective an automated system of the coordination of traffic schedule for a great amount of group trains at an enormous network ground can be created on the basis of the obtained mathematical model. Such an approach will allow increasing the level of transport management, accelerating the terms of freight delivery and increasing the competitiveness of railways on the market of transport services.

Key words: train schedule, group trains, synchronization schedule, automation.

Рецензент д.т.н., професор Бутько Т. В. (УкрдУЗТ)

Поступила 28.08.20152.

Киман А.М., здобувач кафедри управління вантажною $i$ комериійною роботою, Украӥнський державний університет залізничного транспорту, Харків, Україна.

Kyman A., Applicant for a degree at the department of freight and commercial work, Ukrainian State University of Railway Transport, Kharkiv, Ukraine. 